\title{
Analysis on Obama's Eulogy for Mandela
}

\author{
Jingming Chen* \\ School of Foreign Language, Pingxiang University, Pingxiang City, Jiangxi Province 337000, China \\ Corresponding Author: Jingming Chen, E-mail: Chenbrian2009@gmail.com
}

\section{ARTICLE INFO}

Article history

Received: October 09, 2018

Accepted: December 18, 2018

Published: February 28, 2019

Volume: 10 Issue: 1

Advance access: January 2019

Conflicts of interest: None

Funding: None

\begin{abstract}
This paper aims to analyse Obama's eulogy for Mandela. After careful reading and analysis, the eulogy was found to have met al. the requirements of an eulogy, such as the two expectations, and five functions, which are the focus of the study of this paper. Meanwhile, the life story about both Mandela and Obama have been briefly examined, and their similarity in their experience of a multiracial society explains Obama's sympathy with Mandela's life, and their common view on a multiracial society in which all the people can enjoy freedom, equality, and democracy, no matter what races they belong to.
\end{abstract}

Key words:

Obama,

Eulogy for Mandela,

Discourse Analysis

\section{A BRIEF DESCRIPTION OF THE APARTHEID HISTORY OF SOUTH AFRICA AND THE LIFE OF MANDELA}

\section{The Apartheid History of South Africa}

In Africa, before the European white colonizers came, there had already been the indigenous people who had lived there for thousands years. In Africa, the first or the earliest living people were the San and Khoekhoe peoples (otherwise known individually as the Bushmen and Hottentots or Khoikhoi; collectively called the Khoisan). Both were resident in the southern tip of the continent for thousands of years before its written history began with the arrival of European seafarers. And these indigenous peoples had lived a very peaceful life, made a successful living by hunting, herding or farming, and had been very harmonious with nature of that continent. But all of such harmonious lives were suddenly disturbed by that arrival of the European invaders beginning in 1652, when The Dutch East India Company landed the first European settlers on the Cape of Good Hope. From that year, and especially after the year 1795 when the British arrived and occupied the Cape colony, the western white has launched a long term of colonization of this South Africa land. The white saw them as the human selected by the God, so they thought them superior to the indignant people, hence they believed they had the right to "lead" the black people to a higher level of culture and civilization. So the history of
South Africa is mainly the history of White's colonization on the Black and other colored people living in the country.

Under the influence of the idea of the white supremacy, and in order to intensify and ensure the benefit of the white people, and though some certain forms of segregation or apartheid has existed since the beginning of the colony, Apartheid was adopted as a formal policy by the South African government after the election of the National Party (NP) at the 1948 general election. according to the Apartheid policy,all the colonized peoples in Africa must see them as an inferior race, and, therefore, all of them must be separated from the whites, must live separately in the poorer rural area. For example, The Group Areas Acts of 1950 and 1986 forced about 1.5 million Africans to move from cities to rural townships, where they lived in abject poverty under repressive laws, and must not have the right to vote, for example, black voters were removed from the voter rolls in 1936.

\section{The Life of Mandela}

Nelson Rolihlahla Mandela18 July 1918 - 5 December 2013) was a South African anti-apartheid revolutionary, political leader, peace activist, and philanthropist who served as President of South Africa from 1994 to 1999 . He was the country's first black head of state and the first elected in a fully representative democratic election. His government focused on dismantling the legacy of apartheid by tackling institu- 
tionalised racism and fostering racial reconciliation. Ideologically an African nationalist and socialist, he served as President of the African National Congress(ANC) party from 1991 to 1997. In his Eulogistic Speech, Obama traced the course of Mandela's life: from his childhood herding cattle to the legal training that shaped a liberation struggle as great as that of Mahatma Gandhi and Martin Luther King Jr. He retold the story of Mandela's trial in 1964, his decades (as long as 27years) in prison, and his astonishing presidency as the great reconciler of a country few believed could ever heal from the violence and injustice of apartheid. So, Mandela devoted his whole life to the fight against the reality of the white's repression and the apartheid, and to the emancipation of the black people and other colored people in South Africa. For example, in 1952, Mandela as one of the major leaders, he organized and led the Defiance Campaign against apartheid, and At a Durban rally on 22 June, Mandela addressed an assembled crowd of 10,000 , initiating the campaign protests, for which he was arrested and briefly interned in Marshall Square prison; the arrest and the famous Rivonia Trial (1962-1964), after which he and other fellow activists were sentenced to life imprisonment on 12 June 1964, and in his 27 years' prison life, he never stopped his fighting; and in 1991, after his unconditional release from the prison by the newly elected president De Clerk, he, at the Cape City Hall, gave the speech, declaring his commitment to peace and reconciliation with the white minority. all of these events have built him as one of the great political figures in South Africa.

Mandela was died on 5 December 2013, at the age of 95 , accompanied by his family. The present president Zuma publicly announced his death on television,proclaiming ten days of national mourning, and on 10 December 2013 and at Johannesburg's FNB Stadium, the government held a memorial service which about 90 representatives of foreign states attended. By the time of his death, with his greatness in political career and his charismatic personality, such as high image consciousness, loyalty, inclusiveness,simpleness, friendliness, and even a mischievous sense of humor, within South Africa Mandela was widely considered both "the father of the nation" and "the founding father of democracy".Outside of South Africa, he was a "global icon",with the scholar of South African studies Rita Barnard describing him as "one of the most revered figures of our time".(Ibid)

\section{THE EARLY LIFE OF OBAMA, AND ITS INFLUENCE REFLECTED IN THE RELATIONSHIP BETWEEN OBAMA AND MANDELA AND SOUTH AFRICA}

Obama was born to a white mother and a black father. His mother, Ann Dunham (1942-1995), was born in Wichita, Kansas; she was mostly of English descent,with some German, Irish, Scottish, Swiss, and Welsh ancestry.His father, Barack Obama Sr. (1936-1982), was a married Luo Kenyan man. Obama's parents met in 1960 in a Russian language class at the University of Hawaii at Manoa, where his father was a foreign student on a scholarship. The couple married in Wailuku, Hawaii on February 2, 1961, six months before Obama was born. (Ibid). But Obama's parents divorced in March 1964 when his father Obama Sr. came back to Kenya where he had his third marriage. After that, his mother married a Indonesian students who came from Indonesian and studied in America. Two years later after they married, his mother with him followed her Indonesian husband to Indonesia where he studied at the local language school and elementary school from age six to ten, hence the ability to speak Indonesian fluently. When Obama was 11 in 1971, he came back to Honolulu to live with his maternal grandparents.

So the family background of Obama is diversified and extended one, just as Obama himself put it, "It's like a little mini-United Nations", and he said. "I've got relatives who look like Bernie Mac, and I've got relatives who look like Margaret Thatcher. That is, Obama has a half sister from his Indonesian stepfather, and seven half-siblings from his Kenyan father. And Obama also has roots in Ireland; he met with his Irish cousins in Moneygall in May 2011. the multi-racial background of his family background, together with his experiences of a variety of cultures in a climate of mutual respect in Honolulu Hawaii, has became an integral part of his world view, and a basis for the values that he hold most dear, which also shows the relationship and similarity between him and Mandela in the view of the multiraces in a community or country. Obama, as introduced as "our very son of the African soil" in Mandela's memorial service, said,

"It is hard to eulogize any man," Obama began, "to capture in words not just the facts and the dates that make a life, but the essential truth of a person - their private joys and sorrows; the quiet moments and unique qualities that illuminate someone's soul."

And as most people know, during his quiet moments before he ran up for the president, Obama hung several photos on the wall of his Senate office. Unlike other politicians with longer careers, the wall was not full of grinning photos of himself with other luminaries. Instead there were iconic photos of Gandhi, King, and Lincoln: the three historic figures that he cited in his Mandela eulogy. So we know, that, from the very beginning, Obama has regarded Mandela and Gandhi, King, and Lincoln as his icons who share with him the idea that all races should be equal, mutual-respected, peacefully co-existed in a society. Also from his early life when he was still a college student, he showed his sympathy with South African blacks and Mandela's struggle, and his hatred of the Apartheid policy. For example, when he studied in Occidental college, he advocated the Occidental to participate in the disinvestment in South Africa in response to Apartheid in that country.

Though in his eulogy for Mandela, Obama doesn't make comparison between them both as presidents and some special figures in the world, the Mandela example of leadership that Obama describes carries echoes of the style he has tried to adopt himself:(Richard Wolffe, 2013).

"It was precisely because he could admit to imperfection - because he could be so full of good humor, even mischief, despite the heavy burdens he carried - that we loved him so," Obama said. "He tells us what is possible not just in the pages of history books, but in our own lives as well." 
As we can know from the media, Obama warned from the outset of his presidential campaign that he was not a saint - not "a perfect vessel" as he put it. And In office, especially in the deeply troubled start of his second term, he has been more than ready to share publicly "his doubts and his fears; his miscalculations along with his victories." (Richard Wolffe, 2013).

As for political philosophy, Obama, as Mandela does, believe in the combination between the hope and power, or the relationship between what he called "struggle and shrewdness, and persistence and faith, which he adopted from his earliest political career as the community organizer, when he rejected the model of the socialist radicals in favor of the inspiration of civil rights and liberation leaders like Gandhi, King and Mandela. He understood the power of King's dream and President Lyndon Johnson's civil rights laws, and tried to combine a sense of hope and the exercise of power in his own career:

"Mandela taught us the power of action, but he also taught us the power of ideas; the importance of reason and arguments; the need to study not only those who you agree with, but also those who you don't agree with," Obama explained, before insisting that Mandela's achievements were "chiseled into law and institutions."

The similarity between Obama and Mandela in their multiracial experience and their common view on a equal relationship between different races within a society, makes Obama show great sympathy in Mandela's death and his eulogy for Mandela is one of the most moving, influential in human history. The following parts will deal with the basic parts of a eulogy, with the aim to show their sympathy and their common ideal of a racially equal and free society.

\section{TWO EXPECTATIONS IN THE EULOGY}

In the stadium where more than 80 thousands South African people and almost 90 leaders of foreign states were present, Obama's eulogy elicited the most exciting response from the audience. Obama's speech adhered to the generic requirements of a eulogy, while it also incorporated aspects of the kategoria genre and apologia genre.

\section{Obama Expressed Appropriate Personal and Audience Grief}

"Madiba's passing is rightly a time of mourning, and a time to celebrate a heroic life. But I believe it should also prompt in each of us a time for self-reflection. With honesty, regardless of our station or our circumstance, we must ask: How well have I applied his lessons in my own life? It's a question I ask myself, as a man and as a president."

\section{The President Obama Spent Significant Parts of his Speech to Deepen Appreciation and Respect for the Deceased}

"The questions we face today — how to promote equality and justice; how to uphold freedom and human rights; how to end conflict and sectarian war - these things do not have easy answers. Nelson Mandela reminds us that it always seems impossible until it is done. South Africa shows that is true. South Africa shows we can change, that we can choose a world defined not by our differences, but by our common hopes. We can choose a world defined not by conflict, but by peace and justice and opportunity."'[ibid]

"It is hard to eulogize any man," Obama began, "to capture in words not just the facts and the dates that make a life, but the essential truth of a person - their private joys and sorrows; the quiet moments and unique qualities that illuminate someone's soul.'[ibid]

"It was precisely because he could admit to imperfection - because he could be so full of good humor, even mischief, despite the heavy burdens he carried - that we loved him so," Obama said. "He tells us what is possible not just in the pages of history books, but in our own lives as well."'[ibid]

"Given the sweep of his life, the scope of his accomplishments, the adoration that he so rightly earned, it's tempting I think to remember Nelson Mandela as an icon, smiling and serene, detached from the tawdry affairs of lesser men."'[ibid]

\section{FIVE FUNCTIONS}

\section{Obama Tried to Establish the Reality of Death to a Disbelieving Audience}

"It is hard to eulogize any man.How much harder to do so for a giant of history, who moved a nation toward justice, and in the process moved billions around the world."[ibid]

"For the people of South Africa, for those he inspired around the globe, Madiba's passing is rightly a time of mourning, and a time to celebrate a heroic life."[ibid]

"We will never see the likes of Nelson Mandela again. But let me say to the young people of Africa and the young people around the world -- you, too, can make his life's work your own."[ibid]

\section{Obama Tried to Console the Audience by Arguing that the Deceased "Lives On" in Some Capacity Through Various Forms}

"To the people of South Africa -- people of every race and walk of life -- the world thanks you for sharing Nelson Mandela with us. His struggle was your struggle. His triumph was your triumph. Your dignity and your hope found expression in his life. And your freedom, your democracy is his cherished legacy."[ibid]

"We will never see the likes of Nelson Mandela again. But let me say to the young people of Africa and the young people around the world -- you, too, can make his life's work your own.'"[ibid]

"After this great liberator is laid to rest, and when we have returned to our cities and villages and rejoined our daily routines, let us search for his strength. Let us search for his largeness of spirit somewhere inside of ourselves."[ibid]

"What a magnificent soul it was. We will miss him deeply. May God bless the memory of Nelson Mandela. May God bless the people of South Africa.'[ibid] 
"He was not a bust made of marble; he was a man of flesh and blood - a son and husband, a father and a friend. That is why we learned so much from him; that is why we can learn from him still."[ibid]

By saying that "That is why we learned so much from him; that is why we can learn from him still." and "We will miss him deeply." Obama tried to identify Mandela with the common people including the audience to console them that Mandela is just the same as his people both physically and mentally, so the spiritual legacy of Mandela will be able to be transmitted to the following generations, if they are willing to do so.

\section{Obama Sought to Change the Relationship between the Living and the Dead From Present to Past Tense}

"The struggles that follow the victory of formal equality or universal franchise may not be as filled with drama and moral clarity as those that came before, but they are no less important. For around the world today, we still see children suffering from hunger and disease. We still see run-down schools. We still see young people without prospects for the future. Around the world today, men and women are still imprisoned for their political beliefs, and are still persecuted for what they look like, and how they worship, and who they love. That is happening today.[ibid]

And so we, too, must act on behalf of justice. We, too, must act on behalf of peace."[ibid]

Here, the speaker compares the present situation with the past situation through changing the tense from the present tense into past tense, resulting the change of the relationship between the living and the dead.

\section{Obama Reaffirmed a Sense of Identity for the Community}

"And finally, Mandela understood the ties that bind the human spirit. There is a word in South Africa -- Ubuntu -- a word that captures Mandela's greatest gift: his recognition that we are all bound together in ways that are invisible to the eye; that there is a oneness to humanity; that we achieve ourselves by sharing ourselves with others, and caring for those around us."[ibid]

\section{Obama Helped the Audience Deal with Their Own Sense of Mortality}

"He was not a bust made of marble; he was a man of flesh and blood -- a son and a husband, a father and a friend."'[ibid]

Throughout his speech, Obama, though he himself admitted it is a temping for him to "to remember Nelson
Mandela as an icon" given the scope of Mandela's accomplishment, Obama tried to remind the audience that Mandela is not a saint, not a perfect man,which Mandela himself strongly refused, because he also has his doubts, fears and miscalculations along with his victories, and he is also a man made of flesh and blood, -- a son and a husband, a father and a friend. So here, Obama just tried to identify Mandela with their audience, even though Mandela is such a phenomenal figure. And, moreover, he did not mention any religion and spirituality. All of these tend to be the referents to help the audience deal with their own sense of mortality.

\section{CONCLUSION}

Obama's multicultural background of his family and his early life has shaped his view on a mulch-cultural society in which all the races should be free, equal, mutually respected, and peacefully co-existed. Such a multicultural background has also laid the foundation of his sympathy with the black people in South Africa, and with Mandela's struggle against the apartheid policy. In his eulogy for Mandela, Obama highly praised Madela as the last great liberator of the $20^{\text {th }}$ century, who has devoted his whole life to fight for the emancipation of the black and all other colored people from the oppression of the white's government, and whose life, accomplishment, and adoration, according to the words of Obama, has tempted him to remember Mandela as an icon. This eulogy meets all the requirements of a eulogy. In the eulogy, Obama expressed his personal and the audience's grief for the loss of Mandela, but he also tried to console the audience and himself by saying that the freedom, the democracy achieved by Mandela and his people is the most cherished legacy of the country. At the end of the eulogy, after the praise, the grief, and after the reluctant acceptance of a great loss, Obama ends his eulogy with Mandela's favorite poem, Invictus, which said: " 'I am the master of my fate. I am the captain of my soul.' What a magnificent soul it was. We will miss him deeply."

\section{REFERENCES}

Richard, W. (2013). Obama's Moving Eulogy for Nelson Mandela. http://www. msnbc. Com/msnbc/giant-history http://en.wikipedia.org/wiki/Nelson_Mandela. http://en.wikipedia.org/wiki/Barack_Obama.

http:/www.washingtonpost.com/world/obamas-speech-atmandela-memorial-mandela-taught-us-the-power-ofaction-but-also-ideas.

http://www. foxnews.com/story/2007/08/31/text-prince-harry-eulogy-for-princess. 